\title{
PEAT-FORMING ENVIRONMENT OF PERMIAN COAL SEAMS FROM THE FAXINAL COALFIELD (PARANÁ BASIN) IN SOUTHERN BRAZIL, BASED ON PALYNOLOGY AND PALAEOBOTANY
}

\author{
MIRIAM CAZZULO-KLEPZIG, MARGOT GUERRA-SOMMER, RUALDO MENEGAT \\ Instituto de Geociências, UFRGS, Av. Bento Gonçalves, 9500, 91501-970, Porto Alegre, RS, Brazil. \\ miriam.klepzig@ufrgs.br,margot.sommer@ufrgs.br, rualdo.menegat@ufrgs.br
}

MARGARETE WAGNER SIMAS

Programa de Pós Graduação em Geociências, UFRGS, Av.Bento Gonçalves, 9500, 91501-970, Porto Alegre, RS, Brazil. margaws@terra.com.br

\section{JOÃO GRACIANO MENDONÇA FILHO}

Instituto de Geociências, UFRJ, Prédio de Ciências e Matemática, Bloco F, Ilha do Fundão, 21941-590, RJ, Brazil.

\author{
graciano@ufrj.br
}

\begin{abstract}
Coal seams from the Faxinal coalfield (Rio Bonito Formation, Lower Permian of Paraná Basin) are compositionally distinct from other South Brazilian coal palynofloras. The dominance of bisaccate and striate pollen grains such as Alisporites, Scheuringipollenites, Limitisporites, Vesicaspora and Protohaploxypinus in the palynofloras reflect a peat-forming plant community composed namely of glossopterids, cordaites and conifers. Subordinate trilete spores derived from lycopsids, sphenopsids and filicopsids (e.g. Lundbladispora, Punctatisporites, Granulatisporites, Leiotriletes, Deltoidospora, Calamospora) are less abundant, occurring in variable proportions. Algae-like elements, commonly found in south Brazilian coal palynofloras (Portalites, Tetraporina, Brazilea and Quadrisporites), are scarce and Botryococcus was not recorded. This palynological feature as well as the record of abundant woody tissues, cuticles and other phyterals is quite different from palynoassemblages identified in other southernmost Brazilian coal seams. The dominance of woody seed plants in the Faxinal peat-forming vegetation, low proportion of pteridophytic plants and scarcity of algal elements suggest a different peat-forming environment for the Faxinal coal seams compared to other coals from Brazil that have been studied. By integration of palynological and macrofossil data with available sequence stratigraphical studies on the coal-bearing strata in south Brazilian Paraná Basin, a landscape unit has been outlined, that is different from that proposed for the Candiota coalfield. Faxinal coals were interpreted to have accumulated in inland coastal plain mires, linked to delta fluvial settings, at relatively high sea-level, but under low marine influence.
\end{abstract}

Key words: Coal palynofloras, peat-forming flora, palaeoecology, Faxinal coalfield, landscape unit, Paraná Basin, Brazil.

RESUMO - A palinoflora dos carvões da jazida do Faxinal (Formação Rio Bonito, Permiano Inferior, bacia do Paraná) caracteriza-se por uma composição palinológica distinta daquelas reconhecidas para outros carvões do sul do Brasil. O predomínio de grãos de pólen bissacados e estriados, como Alisporites, Limitisporites, Scheuringipollenites, Vesicaspora e Protohaploxypinus reflete a presença de uma vegetação formadora das turfeiras constituída principalmente por glossopterídeas, cordaites e coníferas. Esporos triletes derivados de licófitas, esfenófitas e filicófitas, abundantes na maioria das palinofloras dos carvões sul-brasileiros, como Lundbladispora, Punctatisporites, Granulatisporites, Leiotriletes, Calamospora, Deltoidospora, Cristatisporites e Vallatisporites, ocorrem em baixa proporção. Representantes do grupo das algas (Botryococcus) e elementos incertae sedis ou acritarcas, comumente identificados nos carvões da Bacia do Paraná (Portalites, Tetraporina, Brazilea e Quadrisporites), ocorrem em baixíssima frequência. Estas características palinológicas, associadas à identificação de abundantes fragmentos de lenho, cutículas e outros fiterais relacionados a glossopterídeas e cordaites, evidenciam significativa diferença na composição da vegetação formadora das turfeiras, provavelmente originada por mudanças nas condições do paleoambiente. A partir da integração dos dados microflorísticos, megaflorísticos e paleoecológicos com modelos deposicionais já definidos para sucessões de carvão no sul da Bacia do Paraná com base em estratigrafia de seqüências, foi reconstruída, de modo tentativo, a unidade de paisagem condicionadora da acumulação da turfa geradora dos carvões de Faxinal. A unidade de paisagem proposta, diferente daquela indicada para a jazida de Candiota, é relacionada a áreas mais internas de planície costeira, vinculada à sistema fluvio-deltaico, em nível relativo de mar alto, porém com influência marinha menos marcada.

Palavras-chave: Palinologia de carvões, megafloras, jazida de Faxinal, paleoecologia, unidade de paisagem, bacia do Paraná, Brazil. 


\section{INTRODUCTION}

Many depositional models of coal formation have been described in the literature (Stach et al., 1982; McCabe, 1987; Diessel, 1992; DiMichele \& Phillips, 1994; Nowak \& GóreckaNowak, 1999) often using different kinds of data for the reconstruction of the original environment. Coal petrography, palynology, palaeobotany, organic geochemistry, and sequence stratigraphy are usually the main methods used to define the features of coal depositional environments. The palynological composition of coals has been widely applied to characterize the peat-forming environment, considering that pollen and spores overwhelmingly derive from the peatforming flora and thus reflect the compositional changes that occurred during peat accumulation.

Considering that vegetation is very sensitive to slight environmental changes, reflected in palaeofloristic composition, the association of palynological studies with palaeofloristic data can provide important information on the ecological preferences of different plant groups, original edaphic conditions, and mire hydrology, as well as changes in these variables during the interval of peat formation (Smith, 1962). On the other hand, the interpretation of miospore succession within coals is based on the assumption that the miospore-forming plants are autocthonous or hypoautocthonous and represent a local population of parent plants.

The most important studies on the peat-forming vegetation of the South Brazilian coals (Figure 1) were those of Marques-Toigo \& Corrêa da Silva (1984), Guerra-Sommer et al. (1991) and Corrêa da Silva (1991) which integrated palynology, palaeobotany and coal petrography in an attempt to define the main organic constituents of the coals. Their results demonstrated that these coals have characteristics that are indicative of an origin in limno-telmatic moors, where pteridophytic herbaceous and arborescent plant material accumulated after some transport, promoting hypoautochthonous coal seams.

On the other hand, sequence stratigraphical studies applied to the main coal-bearing strata in southernmost Brazil (Paraná Basin) demonstrated that whereas some coal seams were predominantly originated in fluvial settings, the most important coal beds derived from a lagoon-barrier system linked with a third-order transgressive systems tract, subdivided into four parasequences sets, each set representing a major transgressive pulse in the sedimentary history of the basin (Holz, 1998; Holz \& Vieira, 2001; Holz \& Kalkreuth, 2004).

Palynological studies conducted on the most important coal-bearing strata in the southern Paraná Basin, mainly those

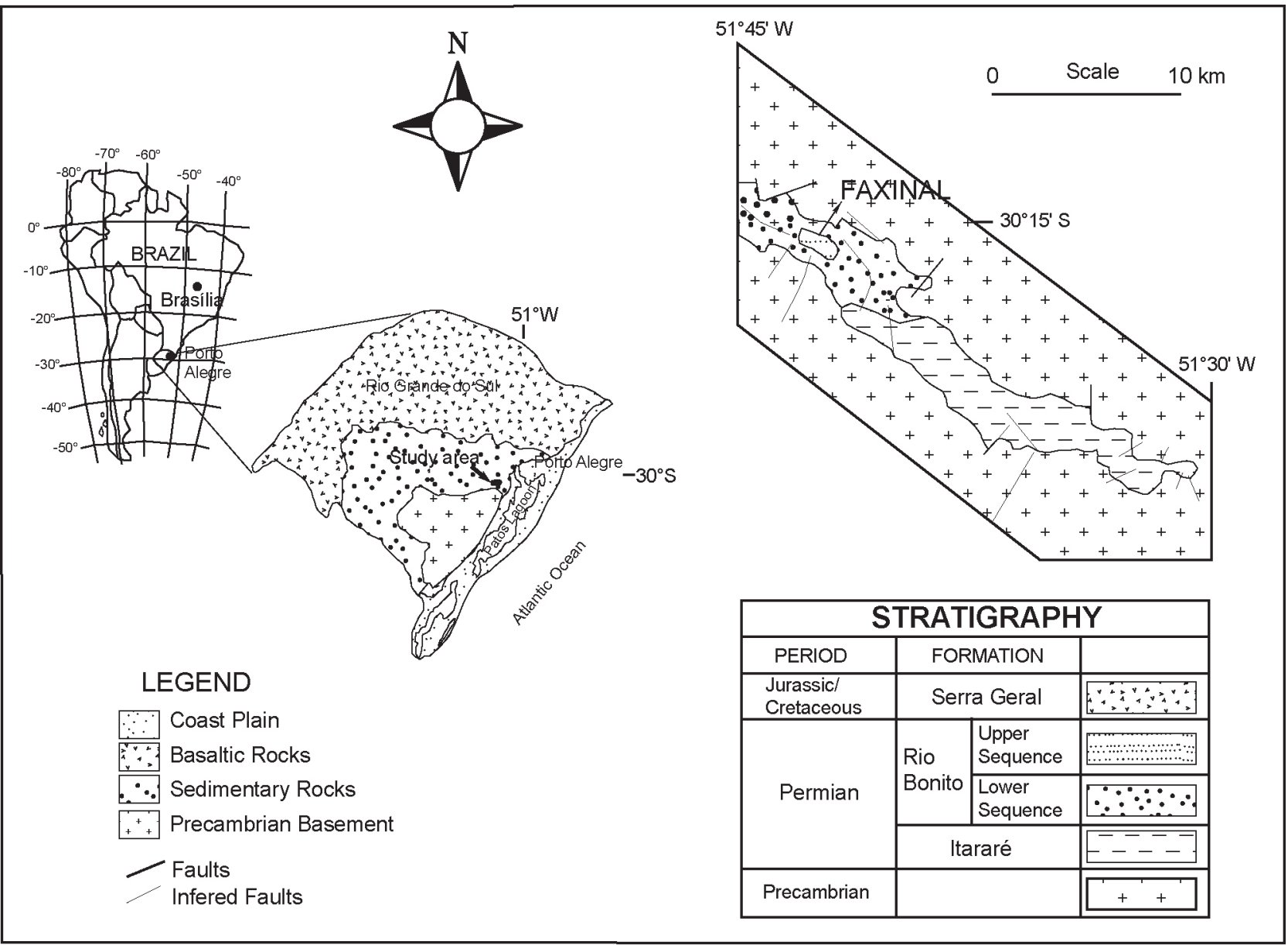

Figure 1. Location map of the Faxinal coalfield and stratigraphic chart of the Paraná Basin. 


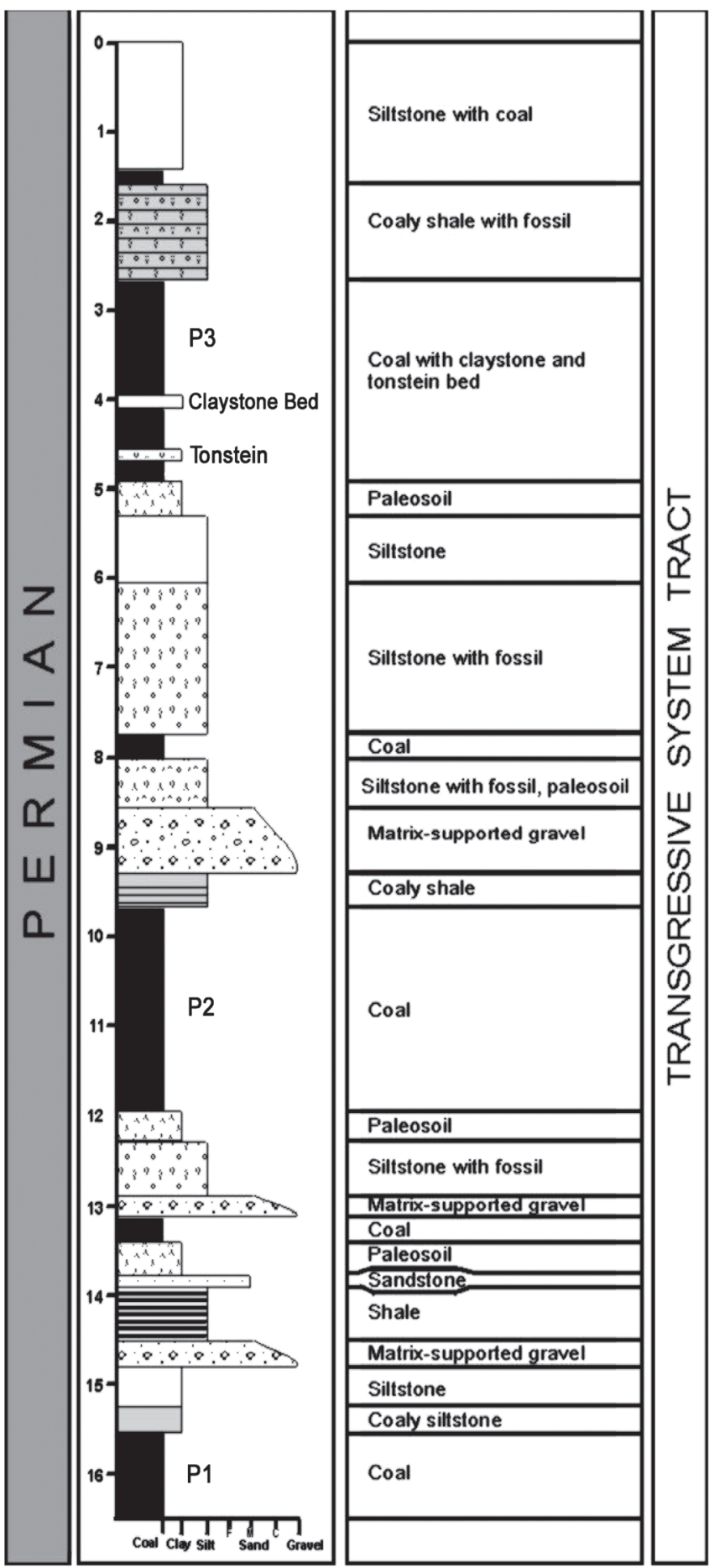

Figure 2. Lithostratigraphic profile of the Faxinal coal succession indicating the beds were the studied samples were collected (P1, $\mathrm{P} 2$, and $\mathrm{P}$ 3).

of Ybert (1975), Burjack (1978), Dias-Fabrício (1981), Bortoluzzi et al. (1980), Cazzulo-Klepzig et al. (1982), Corrêa da Silva et al. (1984), Marques-Toigo et al. (1984), Picarelli et al. (1987), Araújo et al. (1985) and Meyer (1999), demonstrated, in a general way, the presence of rich and diversified palynofloras, dominated by spores derived from herbaceous and arborescent lycopsids. Gymnosperm pollen grains appeared as subordinate components in the palynofloras. In addition, for the majority of the palynoassemblages, organic-walled palynomorphs of doubtful botanical affinity related to algaelike elements or acritarchs were commonly recorded together with fragments of Botryococcus braunii.

Although this type of palynoassemblage has been identified for the majority of South Brazilian coals, some compositional differences, however, have been noted for a few coal seams, mainly in terms of the relative abundances of the most important taxa.

Cazzulo-Klepzig (2002) outlined a hypothetical reconstruction for the landscapes of peat-forming environments related to the most important coal seams in the southern Paraná Basin. This study was based on the composition of the palynofloras, botanical affinity of spores and pollen grains, habit of the parent plants, environmental conditions favorable for the growth of the vegetation, quantitative changes in the palynological content among distinct coal beds, and the range of tolerance to changes in salinity shown by algae and algae-like elements. The author emphasized, however, that although palynology and palaeobotany are very useful tools for environmental reconstruction, the limitations of these methods should be taken into account (e.g.: Di Michele \& Phillips, 1994).

For the Candiota coal seams, which represent the most economically valuable coals in Rio Grande do Sul State (Figure 1), Cazzulo-Klepzig et al. (2005) outlined a tentative palaeoreconstruction of the peat-forming environment of the two most important coal seams (lower and upper Candiota coal seams). For a paleoenvironmental interpretation, sequence stratigraphical information (Holz, 1988; Holz \& Vieira, 2001; Holz \& Kalkreuth, 2004) was integrated with the palynological and paleobotanical data.

Two distinct scenarios were delineated, related respectively to high sea-level conditions and low sea-level conditions. The peats accumulated in paralic conditions, specifically a lagoon-barrier system, and were influenced by episodic sea-water floods (Figure 2). Although the lowland coastal mires could be sporadically flooded, they were isolated from direct marine influence by a barrier island, precluding major marine ingressions. Meyer (1999) recorded the presence of Navifusa and Cymatiosphaera in the Lower Candiota coal palynofloras and expanded the paleoenvironmental interpretation for the coal formation.

Focusing on the Charqueadas coalfield, Cazzulo-Klepzig et al. (1993) noted the strong compositional similarity between the palynofloras identified and the Candiota coal palynofloras. The detected changes in the plant-communities among the distinct coal seams, reflecting palynofloristic content, were caused by changes in the peat-forming environment. A palaeoreconstruction of the changing environment formation was tentatively outlined, characterized by lateral and vertical organic facies.

For the Faxinal coalfield, the focus of this paper (Figure 1), Guerra-Sommer et al. (1983) provide the only palynological studies on the coal seams and document, from preliminary analyses, the palynological content of the coals. These authors mentioned the presence of spores derived from 
arborescent lycopsids (Lundbladispora) together with rare gymnospermous pollen grains (Potonieisporites), although illustrations of the diagnostic forms were not coincident with the list of the palynotaxa identified. In addition to miospores, abundant and wellpreserved woody fragments and epidermal remains (cuticles) were identified as belonging to gymnosperms. In a tonstein layer interbedded in the uppermost coal seam, a rich compressed megaflora represented by leaves, branches and reproductive structures of glossopterids as well as leaves of cordaites, sometimes preserved as foliar tuffs, was also recorded (Guerra-Sommer, 1983, 1988). Results from analyses of the glossopterid epidermal remains indicate xeromorphic patterns. This author emphasized that remains of cordaites, despite being abundantly represented in the Faxinal megaflora, essentially in the tonstein, are poorly represented in other South Brazilian antracophylic floras.

Together with the pteridophytic spores, Dias \& GuerraSommer (1994) mentioned for these palynofloras a significant amount of Maculatasporites minimus and Maculatasporites gondwanensis, considered by some authors as related to fungi, and abundant pollen grains with botanical affinity with gymnosperms, mainly cordaites, conifers and glossopterids. This palynological composition, very similar to that found in the coal seams, is not a common characteristic of the South Brazilian coal palynofloras. Results from petrographic and geochemical analyses (Guerra-Sommer et al., 1983) have indicated a significant amount of woody plant material, suggesting growth of the peat-forming vegetation in a telmatic environment (forest moor).

Based on petrological analyses of the Faxinal coals, Henz (1986) defined the organic matter as derived from woody material, mainly represented by vitrinite, with subordinate exinite and inertinite constituents, which were accumulated in a telmatic environment (forest moor or peat-forming forest vegetation sensu Hacquebard \& Donaldson, 1969). The maceral composition of coals indicated reducing conditions and a shallow water table.

Data from sequence stratigraphical studies of the Faxinal coal-bearing sequenceare very important for a paleoecological interpretation, but to date have not been published.

The present study takes into account the peculiar composition of the palynofloras, reflecting a different type of peat-forming vegetation than that of other well recognized coal palynofloras from the Paraná Basin. This study was also modulated in order to provide an accurate palynological revision aimed at reviewing and characterizing qualitatively and quantitatively the palynofloristic content as well as defining the peat-forming plant-communities related to the Faxinal coal seams. Additional objectives were to interpret the environmental conditions of peat-accumulation and to reconstruct tentatively the landscape under which Faxinal peats accumulated and differed from the other known Brazilian coals.

\section{GEOLOGICAL SETTING}

The Paraná Basin is a large intracratonic basin, located in the central-east part of the South American Platform, covering a surface area of about 1,700,000 km2. According to Milani et al. (1998) the basin comprises six stratigraphic megasequences bounded by interregional unconformities. The Carboniferous-Early Triassic megasequence includes the major coal-bearing strata related to isolated coalfields cropping out from the southernmost part of Rio Grande do Sul State through Santa Catarina State, to the northern portion of Paraná State (Figure 1). The overall transgressive trend at the top of Itararé Group, the basal sedimentary unit in the study area, is essentially represented by marine deposits and points to a relative rise in sea level rise that was later interrupted during the Rio Bonito deposition. Coal occurrences are historically assigned to the Rio Bonito Formation, a fluvial to marine sandstone and shale- rich lithostratigraphic unit of Early Permian age.

The Faxinal coalfield is located in Guaíba city (UTM N665,5; E432,7). Prior stratigraphical and sedimentological studies (Paim et al., 1983; Piccoli et al., 1983) linked the depositional conditions to the presence of alluvial fans that blocked the fluvial sedimentation creating favorable areas for organic matter accumulation. Applying sequence stratigraphy methods, Holz et al. (2000) and Holz \& Kalkreuth (2004) developed a model for palaeoenvironmental evolution of the coal-bearing strata of the South Brazilian coalfields. In this model, the most economically important coal seams occur within the transgressive tract of Sequence 2 as part of a barrier-lagoon system.

\section{MATERIALS AND METHODS}

For the present study, samples were collected from three coal beds in the Faxinal coal-bearing strata, as indicated in the columnar profile (Figure 2: P1, P2 and P3). Extraction of the palynomorphs from samples was carried out using a routine process developed at the Geological Survey of Canada (GSC). Samples were processed in Schulze's solution (65\% nitric acid, $\left.\mathrm{HNO}_{3}\right)$ saturated with potassium chloride $\left(\mathrm{KClO}_{3}\right)$, and neutralized in potassium hydroxide $(\mathrm{KOH})$, enabling the rapid maceration of palynomorphs. Only samples from coal seams 1 and 2 were taken for the study. Palynomorphs from coal seam 3 were poorly preserved.

A visual count of a minimum of 200 miospores was undertaken to determine the relative proportions of miospore taxa. Palynological slides are stored at the Department of Geology of the Geological Survey of Canada.

Assignments of dispersed spores and pollen grains to their respective parent-plant groups, such as lycopsids, ferns, sphenopsids, glossopterids, cordaites and conifers, were based on compilations of Balme (1995) and Quadros et al. (1995). Paleoecological interpretation for the other organic-walled palynomorphs followed mainly concepts adopted by Tiwari et al. (1994), Batten \& Grenfell (1996), Guy-Ohlson (1992), Cazzulo-Klepzig (2001), and accurate criteria of other authors to infer the paleoecology of Botryococcus mentioned below. 


\section{PALYNOLOGY}

There is strong similarity in the palynological results from the main coal seams analysed, with a dominance of bisaccate pollen grains produced by arborescent vegetation, with the following species: Alisporites australis, Scheuringipollenites medius, S. minimus, Limitisporites rectus and Vesicaspora wilsonii. Within this group, Scheuringipollenites and Alisporites are the most abundant bisaccate pollen found (more than 55\%). These pollen grains reflect the remarkable presence of glossopterids in the ancient vegetation (Gould \& Delevoryas, 1977).

Monosaccate forms are common (around 12\%) and show a low species diversity being represented by only three species: Cannanoropollis korbaensis, Potoniesporites braziliensis, and Plicatipollenites malabarensis. Among these, Cannanoropollis is proportionally the most abundant in the assemblage. The number of monosaccate genera identified in the palynoflora indicates that the cordaites also constituted an important component in the palaeoplantcommunities.

Striate pollen grains, reflecting the presence of conifers (more than 12\%) are indicated by the record of distinct species of Protohaploxypinus, mainly Protohaploxypinus limpidus, Protohaploxypinus hartii, and Protohaploxypinus spp.

The number of trilete spores is relatively low and represents only a small proportion of the miospore fraction (around 17\%), which is the opposite of the palynological content in the majority of other South Brazilian coals. The most common spores are derived from sphenopsids and filicopsids (around 10\%): Calamospora sahariana, Calamospora plicata, Convolutispora candiotensis, Deltoidospora directa, Granulatisporites, Granulatisporites micronodosus, Leiotriletes virkki, Punctatisporites gretensis and Murospora torifera. The genus Lundbladispora, the most abundant spore in South Brazilian coals, is rare (3\%). Palynological studies of the tonstein interlayered in the uppermost coal seam indicated a strong similarity between the two palynofloras.

Organic-walled palynomorphs of uncertain botanical affinity (incertae sedis or acritarchs), commonly found in the coal palynofloras of the southern Paraná Basin, such as Portalites, Tetraporina, Brazilea, Quadrisporites and Maculatasporites, are extremely rare in the Faxinal coals (less than 2\%). Cazzulo-Klepzig (2001) emphasized the palaeoecological significance of these palynomorphs for peat-environment reconstruction, particularly their relation to the gradient from fresh, to brackish, to marine conditions. The coccal algae Botryococcus, considered as a good palaeoecological marker, is commonly found in other coal seams but it was not recorded in the Faxinal coals. This microalga has been supposed to be more widespread in lagoonal and lacustrine environments with low salinity (GuyOhlson, 1992), although Botryococcus has been recognized as having a wider tolerance to salinity compared to other microfossils (Grice et al., 1998; Zippi, 1998; Vincent \& Tyson, 1999; Versteegh et al. 2004).
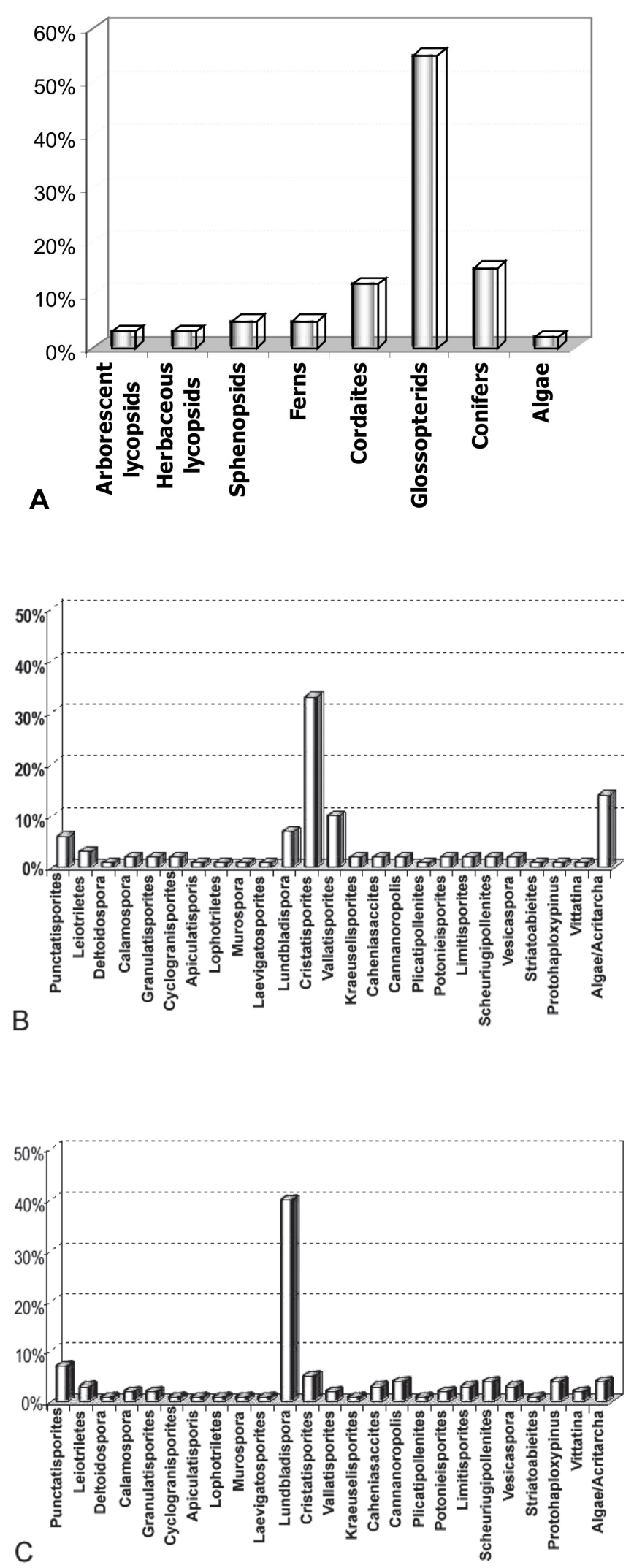

Figure 3. Histograms showing the relative abundance of major group of spores, pollen and other palynomorphs in the Faxinal coal seams (A), in the Lower Candiota coal seam (B); and in the Upper Candiota coal seam (C). 

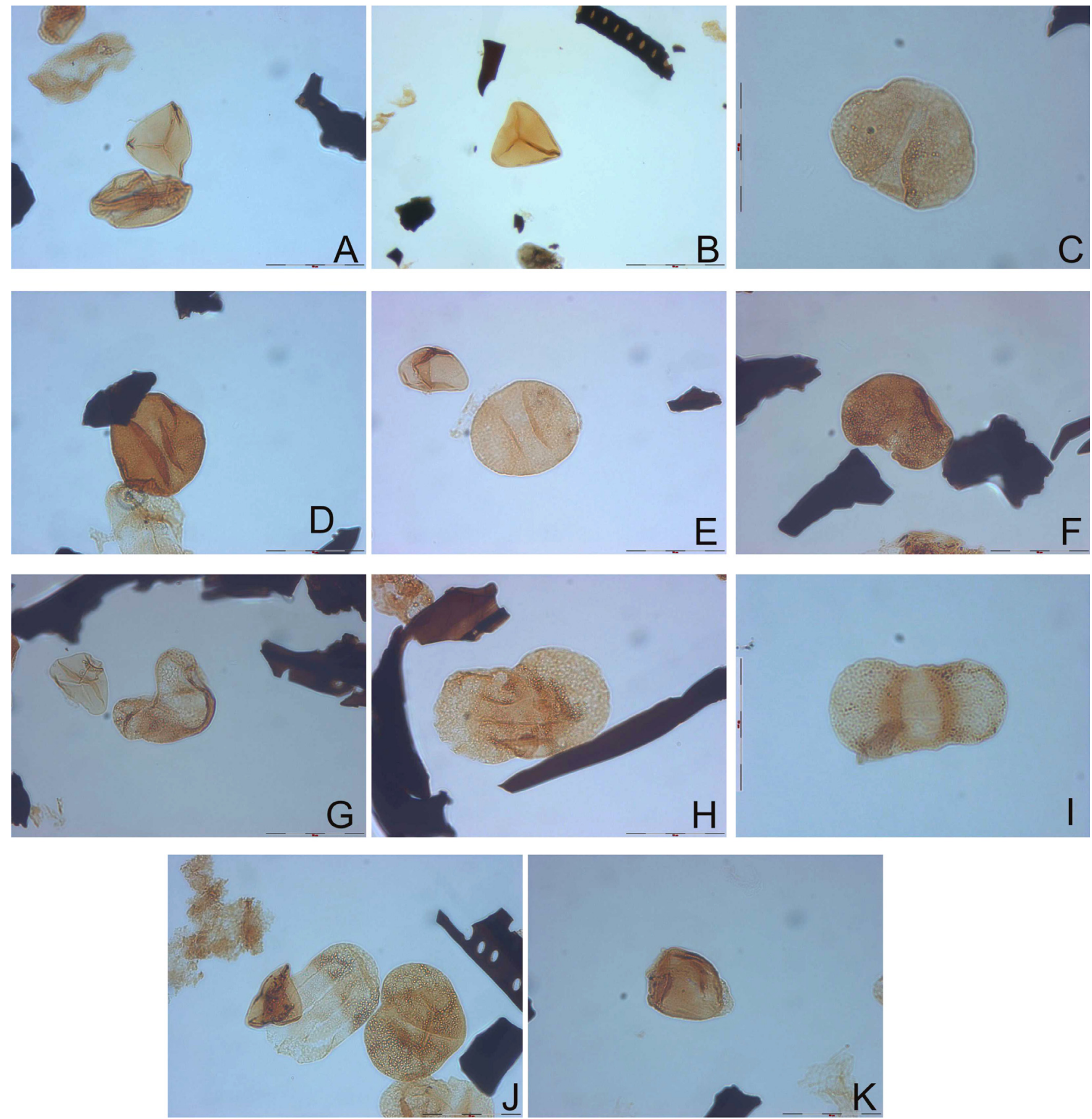

Figure 4. A, Deltoidospora directa (Balme \& Hennely) Hart, 1965 and Calamospora sahariana Bharadwaj, 1953; B, Granulatisporites angularis Staplin,1960; C, Scheuringipollenites medius (Burjack) Dias-Fabricio, 1981; D, Scheuringipollenites ovatus (Balme \& Hennely) Foster, 1975; E, Alisporites splendens (Leschik) Foster, 1979; F-G, Vesicaspora wilsonii (Schemel) Wilson \& Venkatachala, 1963; H, Protohaploxypinus hartii Foster, 1975; I, Protohaploxypinus amplus (Balme \& Hennely) Hart, 1964; J, Protohaploxypinus limpidus (Balme \& Hennelly) Balme \& Playford, 1967; K, Vittatina sp. Each segment of the scale bars is equivalent to $50 \mu \mathrm{m}$.

The palynological content, dominated by pollen derived from arborescent vegetation, and characterized by a scarcity of algal forms, demonstrates significant compositional differences in relation to the coal palynofloras identified in other South Brazilian coals (Cazzulo-Klepzig, 2002). This paleofloristic feature, showing a dominance of woody tissues, tracheids and cuticular fragments was also previously noted in the petrological analyses of Guerra-Sommer et al. (1983) and Henz (1986).

These differences could be caused by topological features or different stages in paleoecological succession (Cairncross \& Caddle, 1998; Glasspool, 2003). In relation to 
the parent plants, although it is possible to outline the probable peat-forming vegetation on the basis of the palynological composition, it is important to take into account that whenever the problem of dispersed spores and pollen is considered, a fossil plant community tends to be underestimated (Traverse, 1988; Nichols, 1995). Cairncross \& Caddle (1998) and Glasspool (2003) describe the complex relationship between the proportion of spores and pollen grains relative to the abundance of their parent plants, considering that the palynological record may not provide a true representation of the types and relative abundance of plants within peat-forming vegetation. Distinct factors such as differential spore and pollen production, introduction into the mires of extraneous, regional pollen grains, and oxidation of the palynological material, can lead to a misrepresentation of the original mire vegetation. On the other hand, organic-walled palynomorphs commonly found in South Brazilian coals, such as algaelike forms and acritarchs, can be often estimated due to different preparation methods (a large-mesh size allows small microfossils to be lost), transport, and potential for preservation. Figure 3 shows a comparison between the relative abundance of the most important plant groups reflected in coal palynofloras of Faxinal and Upper and Lower Candiota.

\section{PALEOENVIRONMENTAL INTERPRETATION}

Different conditions for the peat-formation can be inferred for the Candiota and Charqueadas coalfields, compared to those of Faxinal (Cazzulo-Klepzig et al., 1993, 2005). Considering the peculiar palynological and palaeobotanical features shown by the coals of Faxinal, the palynofloras, which are dominated by glossopterids, small cordaites and conifers, have a low representation of pteridophytic spores, a small fraction of algae-like forms and absence of Botryococcus. On the other hand, the abundance of woody plant material and cuticular fragments belonging to arborescent plants (mainly cordaites and glossopterids), found together with palynological assemblages that reflect the same vegetation (Guerra-Sommer et al., 1983), emphasize the presence of different peat-forming plant communities in relation to those recorded for other South Brazilian coal seams. Although the cordaites, glossopterids and some conifers have been linked to mesophytic-xerophytic environments, for the palaeoenvironment interpretation of Faxinal coalbearing strata, it is important to recognize some of their palaeoecological features, in order to explain their presence in areas adjacent to the mire. According to Guerra-Sommer (1988), the epidermal morphology of the cordaites identified in the Faxinal coals could represent a mechanism to prevent dessication or a response to changes in compositional features of the soil, such as a deficit in $\mathrm{N}$ or in chemical characteristics of the available water in the mires. Such physiological and morphological features could have permitted these plants to partition the ecological resources of the mire.
Cridland \& Morris (1963) and Falcon-Lang (2005) mentioned the very large ecological amplitude of cordaites and the possibility of these plants representing mangrove trees. These papers discussed the possibility that the cordaites occasionally experienced brackish incursions and adapted to elevated salinity by modification of the rooting system and leaves and demonstrated that some species grew in coastal plains. Small cordaites, flourishing in marineinfluenced coastal habitat, in close proximity to the brackish sea coast, adapted to periodically submerged conditions. In the same way, arborescent lycopsids could also tolerate these palaeoecological features (Habib \& Growth, 1967). According to Raymond (1988), some cordaites could live in lowlands, co-occurring with calamiteans, tree-ferns and lycopsids, typical of hygrophylous-mesophylous environments.

According to DiMichele \& Aronson (1992), hydraulic and energetic competition of phothosynthetic and reproductive activities may have made Paleozoic glossopterids, more vulnerable to fluctuations in water supply, influencing their occupation of drier areas adjacent to the mire. Knoll \& Niklas (1987) concluded that xeromorphic structures shown by some glossopterids, as identified in the Faxinal coal seam (Guerra-Sommer et al., 1992), can be indicative that they originally grew in higher lands. In the Permian, they could have migrated to peatforming environments in lowlands, co-occurring with lycopsids, ferns and sphenopsids. The high representation of arborescent glossopterids and cordaites with deciduous leaves and the relatively low abundance of herbaceous plants with perennial leaves in the megaflora of Faxinal are indicative of an hypoauthochtonous taphocenose (Birks \& Birks, 1980). On the other hand, the low compositional variation of the Faxinal megaflora also reflected in the palynoflora, could indicate that the habitat in which these plants grew were intrinsically stressful conditions (DiMichele et al., 1985).

The Faxinal mire landscape was likely located in a more inland area than that of Candiota. In Faxinal, coal was formed in wet forest swamp environments, situated in a marine influenced lower delta plain setting, presenting favorable conditions to the development of arborescent vegetation (Figure 5). This is in opposition to the conditions under which Candiota and Charqueadas coals formed. The dominance of arborescent vegetation, low proportion of arborescent lycopsids and scarce record of algal elements define this scenario (Figure 6).

\section{ACKNOWLEDGMENTS}

The authors especially appreciate the important assistance of J. Utting (GSC) in the laboratory procedures. The authors would like to thank three anonimous reviewers for their constructive and helpful criticism of the manuscript. This research was supported by Conselho Nacional de Desenvolvimento científico e Tecnológico and Fundação de Amparo à Pesquisa do Rio Grande do Sul. 

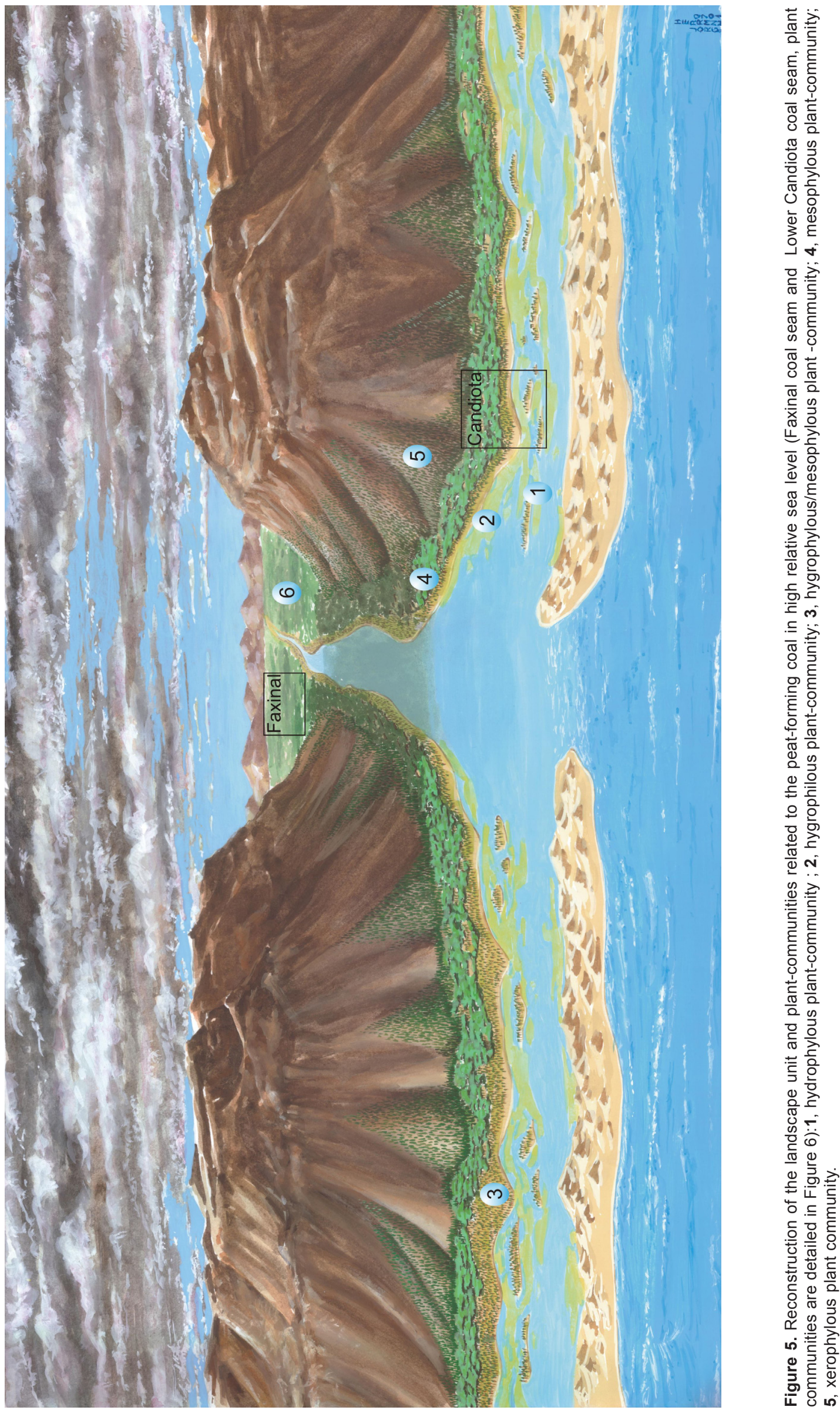


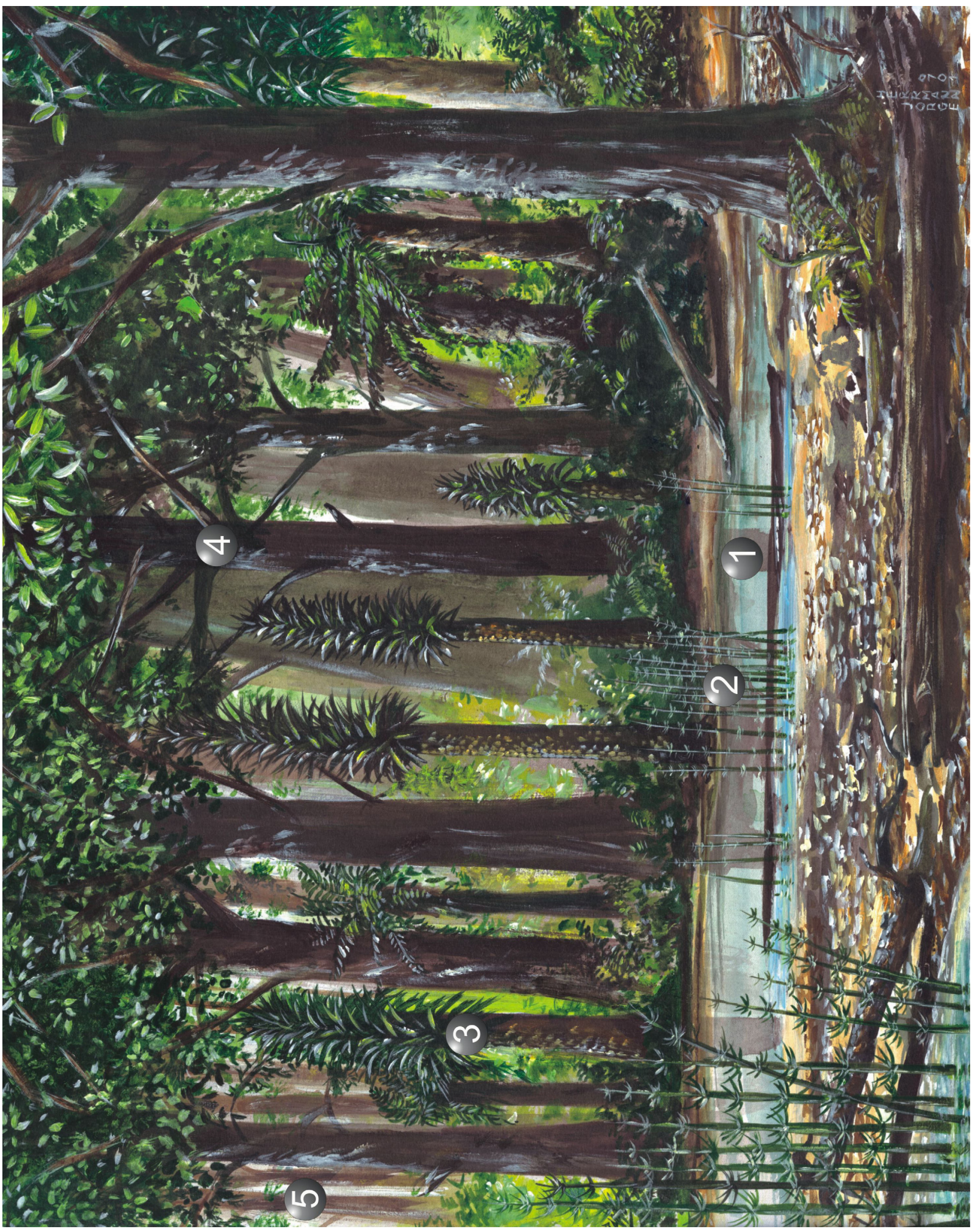




\section{REFERENCES}

Araújo, C.V.; Cazzulo-Klepzig, M. \& Alves, R.G. 1985. Caracterização petrográfica e palinológica dos carvões da jazida carbonífera do Iruí, RS, Brasil. In: SIMPÓSIO SUL-BRASILEIRO DE GEOLOGIA, 2, 1985, Anais, Florianópolis, SBG, p. 449-460.

Balme, B.E. 1995. Fossil in situ spores and pollen grains: an annotated catalogue. Review of Palaeobotany and Palynology, 36:95-163.

Batten, D.J. \& Grenfell, H.R. 1996. Green and blue-green algae Botryococcus. In: J. Jansonius \& D.C. McGregor (eds.) Palynology: principles and applications, American Association of Stratigraphic Palynologists Foundation, p. 205-214.

Birks, H.J.B. \& Birks, H.H. 1980. Quaternary Palaeoecology, $2^{\mathrm{a}}$ ed. E. Arnold Press, London, 236 p.

Burjack, M.I.A. 1978. Estudo palinológico da jazida carbonifera de Charqueadas, Rio Grande do Sul, Brasil. $1^{\mathrm{a} e d ., ~ E d i t o r a ~}$ Universidade Federal de Goiás, Goiânia, 204 p.

Bortoluzzi, C.A.; Guerra-Sommer, M.; Marques-Toigo, M.; Bossi, G.E. \& Andreis, R.R. 1980. Estudo geológico da Bacia Carbonífera de Gravataí-Morungava. In: CONGRESSO BRASILEIRO DE GEOLOGIA, 31, 1980. Anais, Balneário Camboriú, SBG, p. 266-282.

Cairncross, B. \& Caddle, A.B. 1998. Depositional palaeoenvironment of the coal-bearing Permian Vryheid Formation in the east Witbank Coalfield, South Africa. International Journal of Coal Geology, 91:1-17.

Cazzulo-Klepzig, M.; Dias-Fabrício, M.E. \& Marques-Toigo, M. 1982. Palynological characterization of rocks associated to coal seams of Santa Rita Coalfield, Paraná Basin, Permian,Brazil. In: CONGRESSO GEOLOGICO CHILENO, 3, 1982. Actas, Concepción, Universidad de Concepción, v.1, p. 65-83.

Cazzulo-Klepzig, M.; Marques-Toigo, M. \& Corrêa da Silva, Z.C. 1993. Peat-forming environments of the Permian Gondwanic south Brazilian coals. In: ANNUAL MEETING OF THE INTERNATIONAL COMMISSION OF COAL AND ORGANIC PETROLOGY (ICCP), 45, 1993. Abstracts, Chania, p.13-14.

Cazzulo-Klepzig, M. 2001. Significado paeloecológico de alguns palinomorfos ocorrentes nos carvões eopermianos do Rio Grande do Sul, sul do Brasil. Pesquisas, 25(2):59-65.

Cazzulo-Klepzig, M. 2002. Palinologia aplicada à reconstituição das unidades de paisagem e dinâmica das turfeiras formadoras dos carvões permianos do Rio Grande do Sul, Brasil. Programa de Pós-graduação em Geociências, Universidade Federal do Rio Grande do Sul, PhD. Dissertation, 300 p.

Cazzulo-Klepzig,M.; Menegat, R. \& Guerra-Sommer, M. 2005. Palynology and palaeobotany in the reconstruction of landscape units from the Candiota Coalfield, Permian of Paraná Basin, Brazil. Revista Brasileira de Paleontologia, 8(1):83-98.

Corrêa da Silva, Z.C.; Bortoluzzi, C.A.; Cazzulo-Klepzig, M.; DiasFabrício, M.E.; Guerra-Sommer, M; Marques-Toigo, M.; Paim, .P.S.; Piccoli, A.E.M.; Silva Fo., B.C. 1984. Geology of Santa Rita Coal Basin, RS, Brazil. International Journal of Coal Geology, 3:383-400.

Corrêa da Silva, Z.C. 1991. The formation of coal deposits in South Brazil. In: INTERNATIONAL GONDWANA SYMPOSIUM, 7, 1991. Proceedings, São Paulo, Instituto de Geociências/USP, 1:233-241.

Cridland A.A. \& Morris, J.E. 1963. Taeniopteris, Walchia and Dichophyllum in the Pennsylvanian System in Kansas, Science
Bulletin, University of Kansas, 44:71-85.

Dias-Fabrício, M.E. 1981. Palinologia da Formação Rio Bonito na área de Gravataí-Morungava, RS. Pesquisas, 14:69-129.

Dias, M.E.R. \& Guerra-Sommer, M. 1994. Integração entre dados mega e microflorísticos na Jazida do Faxinal, Rio Grande do Sul: estudos preliminares. Acta Geologica Leopoldensia, 39(17):249-260

Diessel, C.F.K. 1992. Coal-bearing depositional system. $3^{\mathrm{a} e d}$, Berlin, Springer, $721 \mathrm{p}$.

DiMichele,W. A. \& Aronson, B. 1992. The Pennsylvanian/Permian vegetational transition: a terrestrial analogue to the onshoreoffshore hypothesis. Evolution, 46:807-824.

DiMichele,W.A. \& Phillips, T.L. 1994. Palaeobotanical and palaeoecological constrains on models of peat-formation in the Late Carboniferous in Euroamerica. Palaeogeography, Palaeoclimatology, Palaeoecology, 106:39-90.

Falcon-Lang, H.J. 2005. Small cordaitalean trees in a marine influenced coastal habitat in the Pennsylvanian Joggins Formation, Nova Scotia. Journal of Geological Society, 162:485500.

Glasspool, I.J. 2003. Hypauthocthonous-allocthonous coal deposition in the Permian, South Africa, Witbank basin n.2 seam: a combined approach using sedimentology, coal petrology and palaeontology. International Journal of Coal Geology, 53:81-135.

Gould, R.E. \& Delevoryas, T. 1977. The Biology of Glossopteris: evidence from petrified seed-bearing and pollen bearing organs. Alcheringia, 1:387-399.

Grice, K.; Schouten, S.; Nissenbaum, A.; Charrah, J. \& SinningheDamsté, J.S. 1998. A remarkable paradox: sulfurised freshwater alga (Botryococcus braunii) lipids in an ancient hypersaline enximic ecosystem. Organic Geochemistry, 28:195-216.

Guerra-Sommer, M. 1982. Coníferas em associações higro-mesófilas no Gondwana brasileiro. In: CONGRESSO BRASILEIRO DE GEOLOGIA, 32, 1982. Anais, Salvador, SBG, p. 1246-1251.

Guerra-Sommer, M. 1988. Padrões epidérmicos da Flora Glossopteris na jazida do Faxinal, Formação Rio Bonito, Kunguriano: implicações taxonômicas, bioestratigráficas, paleoecológicas e paleogeográficas. Curso de Pós-graduação em Geociências, Universidade Federal do Rio Grande do Sul, PhD. Dissertation, 372 p.

Guerra-Sommer, M.; Marques-Toigo, M.; Paim, P.S.G.; Henz, G. I.; Silveira, J.B.R. \& Backeuser,Y. 1983. Estudo microflorístico e petrológico dos carvões da Mina do Faxinal, Formação Rio Bonito (Permiano), RS. Boletim do Instituto de Geociências da USP, 15:73-83.

Guerra-Sommer, M. \& Marques-Toigo, M. \& Corrêa da Silva, Z.C. 1991. Original biomass and coal deposition in Southern Brazil (Lower Permian, Paraná Basin). Bulletin de Societé Géologique de France, 62(2):227-237.

Guerra-Sommer, M.; Marques-Toigo, M. ; Paim, P.S.G. ; Henz, G.I.; Silveira, J.B.R \& Backheuser, Y. 1984. Estudo microflorístico e petrológico da Mina do Faxinal, Formação Rio Bonito( Permiano), RS. 1983. Boletim do Instituto de Geociências da USP, 15:13-150.

Guy-Ohlson, D. 1992. Botryococcus as an aid in the interpretation of the palaeoenvironment and depositional processes. Review of Palaeobotany and Palynology, 71(1/4):1-16.

Hacquebard, P.A. \& Donaldson, R. 1969. Carboniferous coal deposition associated with flood-plain and limnic environment in Nova Scotia. In: E.C. Dapple \& M.E. Hopkins (eds.) Environments of Coal Deposition, Special Paper of Geological 
Society of America, 114:143-191.

Habib, D. \& Growth, P.H.K. 1967. Palaeoecology of migrating Carboniferous peat-environment. Palaeogeography, Palaeoclimatology, Palaeoecology, 3:185-195.

Henz, G.I. 1986. Organo-petrografia e organo-geoquímica dos carvões da Mina do Faxinal, Município de Arroio dos Ratos, RS, Brasil. Curso de Pós-graduação em Geociências, Universidade Federal do Rio Grande do Sul, Master Thesis, 123 p.

Holz, M. 1998. The Eo-Permian coal seams of the Paraná Basin in southernmost Brazil: an analysis of the depositional conditions using sequence stratigraphy concepts. International Journal of Coal Geology, 36:148-163.

Holz, M. \& Kalkreuth, W. 2004. Sequence stratigraphy and Coal Petrology applied to the Early Permian coal-bearing Rio Bonito Formation, Paraná Basin, Brazil. In: J. Pashin \& R. Gastaldo (eds.) Special Publication of Coal Geology, American Association of Petroleum Geology, p. 45-56.

Holz, M. \& Vieira, P.E. 2001. Facies and stratigraphy of the Early Permian coal-bearing succession from the Paraná Basin in the southernmost Brazil. In: R. Weiss (ed.) Contributions to Geology and Palaeontology of Gondwana (in Honour of Helmuth Wopfner), Universitat of Koln, p. 253-262.

Knoll, J. \& Nicklas, E. 1987. Adaptation, plant evolution and the fossil record. American Journal of Botany, 72:886-887.

McCabe, P. S.1987. Facies studies of coal and coal-bearing strata: recent advances. Special Publications of Geological Society, 32:51-66.

Marques-Toigo, M. \& Corrêa da Silva, Z.C. 1984. On the origin of gondwanic south Brazilian coal measures. Comunicações dos Serviços Geológicos de Portugal, 7:151-160.

Marques-Toigo, M; Dias-Fabrício, M.E. \& Cazzulo-Klepzig, M. 1984. A sucessão da microflora nas camadas de carvão na Bacia Carbonífera de Charqueadas, Formação Rio Bonito, RS, Brasil. Boletim do Instituto de Geociências da USP, 15:65-72.

Meyer, K. B. 1999. Caracterização palinológica das camadas de carvão da Malha IV na Mina de Candiota, RS, Permiano da Bacia do Paraná, Brasil. Programa de Pós-graduação em Geociências, Universidade Federal do Rio Grande do Sul, Master Thesis, $112 \mathrm{p}$.

Milani, E.J.; Faccini, U.F.; Scherer, C.M.; Araújo, L.M. \& Cupertino, J.A. 1998. Sequences and stratigraphic hierarchy of the Paraná Basin (Ordovician to Cretaceous), Southern Brazil. Boletim do Instituto de Geociências da USP, 29:125-173.

Nichols, G.J. 1995. The role of palynology in palaeoecological analyses of Tertiary coals. International Journal of Coal Geology, 28:139-160.

Nówak, G.J. \& Gorecka-Nówak, A. 1999. Peat-forming environments of Westphalian coal seams from the Lower Silesian Coal basin of SW Poland based on petrographic and palynological data. International Journal of Coal Geology, 40:327-351.

Paim, P.S.G.; Corrêa da Silva, Z.C.; Cazzulo-Klepzig, M.; Marques-Toigo, M.; Dias-Fabrício, M.E. \& Henz, G.I. 1983. Características petrográficas e palinológicas do perfil das camadas de carvão na sondagem P-4, Bacia Carbonífera de Santa Rita, RS. In: CONGRESSO BRASILEIRO DE GEOLOGIA, 32, Anais. Salvador, SBG, p. 1271-83.

Paim, P.S.G.; Piccoli, A.E.M.; Sarturi, J.A.D.; Holz, M. \& Granitoff, W. 1983. Evolução paleogeográfica do Supergrupo Tubarão na área de Mariana Pimentel-Faxinal, Guaíba, RS. In: SIMPÓSIO SUL-BRASILEIRO DE GEOLOGIA, 1, Atas. Porto Alegre, SBG, p. 125-139.
Pant, D.D. \& Singh, K.B. 1971. Cuticular structures of some Indian Lower Gondwana species of Glossopteris Brongniart - part 3. Palaeontographica B, 135:1-40.

Picarelli, A.T.; Dias-Fabrício, M.E. \& Cazzulo-Klepzig, M. 1987. Considerações sobre a palinologia e a paleoecologia da jazida carbonífera de Santa Terezinha, RS, Brasil, Permiano da Bacia do Paraná. In: SIMPÓSIO SUL-BRASILEIRO DE GEOLOGIA, 3. Atas, Curitiba, SBG, 1:351-372.

Piccoli, A.E.M.; Paim, P.S.G.; Sarturi, J.A.D.; Holz, M.; Munaro, P. \& Granitoff, W. 1983. Geologia do Supergrupo Tubarão na região de Mariana Pimentel-Faxinal, Guaíba, RS. In: SIMPÓSIO SUL-BRASILEIRO DE GEOLOGIA, 1. Atas, Porto Alegre, SBG, p. 125-139.

Quadros, LP.; Marques-Toigo, M. \& Cazzulo-Klepzig, M. 1995. Catálogo de esporos e pólens fósseis do Paleozóico. Boletim de Geociências da Petrobrás, Rio de Janeiro, 9:1-151.

Raymond, P.A. 1988. The palaeoecology of a coal-ball deposit from the Middle Pennsylvanian of Iowa dominated by cordaitalean gymnosperms. Review of Palaeobotany and Palynology, 53:233-250.

Smith, A.H.V. 1962. The palaeoecology of Carboniferous peats based on the miospore and petrography of bituminous coals. Proceedings of the Yorkshire Geological Society, 33:345-363.

Stach, E.; Mackowski, M.T.; Teischmuller, M.; Taylor, G.; Chandra,D. \& Teischmuller, R. 1982. Stach's Textbook of Coal Petrology. $3^{\mathrm{a}}$ ed., Berlin, Gebrüder Borntraeger, 535 p.

Traverse, A. 1988. Palaeopalynology. London, Kluwer Academic Publishers, $600 \mathrm{p}$.

Tiwari, R.S.; Tripathi, A. \& Vijaya 1994. Organic-walled microfossils of doubtful origin in the Permian and Triassic sequences in Peninsular India. The Palaeobotanist, 43:1-58.

Versteegh, G.J. \& Blokker, P. 2004. Resistant macromolecules of extinct and fossil microalgae. Phycological Research, 2:235339.

Vincent, A.J. \& Tyson, R.V. 1999. Organic facies of the Middle Jurassic of the Inner Hebrides, Scotland. Petroleum Geosciences, 5(1):83-92.

Ybert, J.P. 1975. Étude des miospores du Bassin Houiller de Candiota-Hulha Negra, Rio Grande do Sul, Brésil. Pesquisas, 5(1):181-226.

Zippi, P.A. 1998. Freshwater algae from the Mattagami Formation (Albian,Ontário), palaeoecology, botany and systematic taxonomy. Micropaleontology, 44:98 -103.

Received in February, 2007; accepted in July, 2007. 